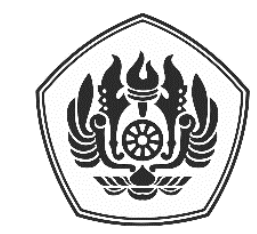

\title{
Padjadjaran Journal of International Law
}

ISSN: 2549-2152, EISSN: 2549-1296

Volume 4, Number 2, June 2020

\section{North Korea's Nuclear Weapon Development in Regards to the Principle of Self Defence in International Law}

\author{
Rahmah Kusumayani*
}

\begin{abstract}
Self defence known as an inherent right that is owned by states to protect its sovereignty from attack by other states. The international rules about self defence do not give any limitation about the type of weapon that can be used by states, including the threat or use of nuclear weapons to act self defence. In Practice, many requirements must be fulfilled by states when they claim the act of self defence. Since 2006, North Korea proclaimed its capability to develop nuclear weapons based on self defence argument. The Security Council concluded that North Korea's development of nuclear weapon program is a threat to international peace and security and condemned such acts with sanctions based on act 41 UN Charter. The purposes of this study are to examine whether the North Korea's nuclear program as an act of self defence and the UN Security Council's sanctions to North Korea are in line with the principle of self defence in international law. The result of this research concludes that North Korea's nuclear program does not meet the requirements as stated in article 51 UN Charter and customary international law regarding self defence. North Korea can not prove that the United States' threat is jeopardy, and has a wide and dangerous effect for North Korea. Regarding the Security Council's primary responsibility to maintain international peace and security, states must report his act of self defence to the Security Council immediately. As therefore, sanctions given by the Security Council are in line with the principle of self defence since North Korea can not fulfil the requested requirements of self defence.
\end{abstract}

Keywords: Act 51 UN Charter, Korean Nuclear Development, Principle of self defence

\section{Pengembangan Senjata Nuklir Korea Utara Dikaitkan dengan Prinsip Self Defence dalam Hukum Internasional}

\begin{abstract}
Abstrak
Hak untuk menerapkan self defence dimiliki oleh tiap negara untuk melindungi kedaulatannya dari serangan negara lain. Peraturan internasional mengenai self defence tidak membatasi jenis senjata yang dapat digunakan oleh negara, termasuk ancaman dan penggunaan senjata nuklir dalam melakukan tindakan self defence. Dalam prakteknya banyak syarat yang harus dipenuhi oleh negara-negara ketika akan mengklaim tindakan self defence. Sejak tahun 2006, Korea Utara mendeklarasikan kesiapannya dalam mengembangkan senjata nuklir dengan alasan self defence. Dewan Keamanan menganggap bahwa program pengembangan senjata nuklir Korea Utara mengancam perdamaian dan keamanan internasional dan berdasarkan Pasal 41 Piagam PBB, Dewan Keamanan memberikan sanksi kepada Korea Utara. Tujuan penelitian ini untuk mengkaji legalitas pengembangan senjata nuklir di Korea Utara atas tindakan yang diklaim negaranya sebagai self defence serta kesesuaian penerapan sanksi Dewan Keamanan PBB dengan prinsip self defence. Hasil dari penelitian ini menyatakan bahwa program senjata nuklir Korea Utara tidak
\end{abstract}

PADJADJARAN JOURNAL OF INTERNATIONAL LAW Volume 4 Issue 2 Year 2020 [ISSN 2549-2152] [e-ISSN 2549-1296]

Judge at District Court of Barabai, Hulu Sungai Tengah, amahkusum@gmail.com 
Defence in International Law

memenuhi syarat yang terdapat dalam Pasal 51 Piagam PBB maupun hukum kebiasaan internasional terkait self defence. Korea Utara tidak bisa membuktikan bahwa ancaman Amerika Serikat bersifat genting dan nyata menimbulkan efek luas dan berbahaya bagi Korea Utara. Berdasarkan tugas utama Dewan Keamanan dalam menjaga kedamaian dan keamanan internasional, negara-negara harus melaporkan tindakan self defence kepada Dewan Keamanan dengan segera. Berdasarkan uraian diatas, sanksi yang diberikan Dewan Keamanan tidak bertentangan dengan prinsip self defence karena Korea Utara tidak bisa memenuhi hal-hal yang disyaratkan untuk melakukan tindakan self defence.

Kata Kunci: Pasal 51 Piagam PBB, Pengembangan Senjata Nuklir Korea Utara, Prinsip Pembelaan Diri

\section{A. INTRODUCTION}

Nuclear weapon is type of Mass Destruction Weapon which has mass destructive effect. ${ }^{1}$ Nuclear weapon were first used in Second World War when the United States attacked Japan by dropped atomic bombs on the city of Hiroshima and Nagasaki. It causes serious damage up to a radius of 15 kilometers and its dangerous added by the radiation that makes people who live in that area suffer and die because of explosion and radiation.

After the Second World War, the nuclear weapon is increasingly spreading but the international community's awareness of the danger and threat of nuclear war is also increasing, so that the international community made various agreements related to nuclear weapons. One of the established treaties was NonProliferation Treaty (NPT) that aimed to limit the number of nuclear weapons in five countries which already owned nuclear weapon when this treaty applied which were United States, Uni Soviet, United Kingdom, France, and China or called "Nuclear-Weapon States (NWS)". ${ }^{2}$ Based on the NPT, the use of nuclear energy is allowed as long as it is used for peaceful purposes and under the supervision of International Atomic Energy Agency (IAEA). ${ }^{3}$ IAEA is an autonomous body under the United Nations in the form of a cooperation forum between countries whose function is to ensure that nuclear materials and equipment are truly used for peaceful purposes. ${ }^{4}$

NPT affirms that these five countries are prohibited from helping other countries to have nuclear weapons. Meanwhile Article 2 of NPT forbid non nuclear weapon state to make any attempt to obtain nuclear weapon or other nuclear explosive device as its said, "Each non-nuclear-weapon State Party to the Treaty undertakes not to receive the transfer from any transferor whatsoever of nuclear weapons or other nuclear explosive devices or of control over such weapons or explosive devices directly, or indirectly; not to manufacture or otherwise acquire nuclear weapons or other nuclear explosive devices; and not to seek or receive any assistance in the manufacture of nuclear weapons or other nuclear explosive devices". ${ }^{5}$

Countries other than the NuclearWeapon States are forbidden to own or develop nuclear weapons in any way and are required to undertake nuclear disarmament in good faith. But in fact, there are still many countries that are reluctant to disarm their nuclear weapons, because they feel that the possession of nuclear weapons has its own advantages for their country.

North Korea is one of the countries outside the NWS that develops its own nuclear weapons. The development of North Korea nuclear weapons started to be known in 1989 when France satellite detected nuclear development activities

\footnotetext{
Ambarwati, Hukum Humaniter Internasional dalam Studi Hubungan Internasional, Jakarta: Raja Grafindo Persada, 2009, p. 9. Dian Wirengjurit, Kawasan Damai dan Bebas Senjata Nuklir, Bandung: Penerbit Alumni, 2002, p. 19.

Non Proliferation Treaty (NPT) 1968, Act.3.

"IAEA History", https://www.iaea.org/about/overview/history, accessed on $8^{\text {th }}$ of December 2016.

Non Proliferation Treaty 1968, Article 1.
} 
conducted in North Korea. ${ }^{6}$ In 2003, North Korea made an open statement that they are ready to develop nuclear weapons. The statement was proved on 9 October 2006 when North Korea announced that the country had tested the nuclear weapons that they had been developed. ${ }^{7}$ The North Korea statement was condemned by various countries and also the United Nations Security Council which condemned North Korea through resolution No. 2276.

North Korea has several profound reasons to develop nuclear programs. First, in the name of self defence, North Korea argues its nuclear development program intended to protect the security of the country especially from United States military attack. Second, to improved the economic field, and third for increase the bargaining position of North Korea in front of other countries. ${ }^{8}$

North Korea's concern for the United States started in 1950 when North Korea was going to attack South Korea. At that time, South Korea was helped by the United States under the United Nations while North Korea was helped by the Uni Soviet. This event is known as the Korean War. Korean War ended in 1953 with the signing of a ceasefire agreement which was not based on a peace agreement. Therefore, North Korea worried that South Korea and the United States will one day attack their country. ${ }^{9}$

Moreover, since North Korea developed its nuclear weapons, the United States under the leadership of George W. Bush listed North Korea into the axis of evil countries list with Afghanistan and Iraq because the United States Government considered North Korea as a threat to the security of the United States and the international community. In response to the

Daniel Wertz, “North Korea's Nuclear Weapons Program", The National Committee on North Korean, 2016, p. 2.

UN SC Resolution 17182006.

Andi Purwono and Ahmad Saifuddin, "Peran Nuklir Korea Utara sebagai Instrumen Diplomasi Politik Internasional", Spektrum: Jurnal IImu Politik Hubungan Internasional, Vol.7, No.2, 2010, p. 6. statement, North Korea concerned that their country was going to be the next target of the United States attack. Therefore, North Korea was increasing its nuclear weapons development to prevent the United States carrying out a military provocation against North Korea. The development of nuclear weapons was claimed as an act of self-defense by North Korea. ${ }^{10}$

International law acknowledges countries' right to protect their territorial integrity from threats that can interfere with their sovereignty by the act of selfdefense. In international law, self-defense is acknowledged by Customary International Law and Positive International Law, which is written on Article 51 of the UN Charter.

Although it is acknowledged as an inherent right and owned by every country, there is no specific regulation regarding any actions included in self-defense that can be implemented by every country. Every country is free at any time, anywhere, and any way to apply self-defense principles to defend its territory from an attack and can decide for itself what is meant by the compelling situation to defend itself. ${ }^{11}$ Lauterpach said that every country must be decisive in its own actions because the country cannot wait for the decision of international authorities to do self-defense actions when they are suddenly attacked.

In the case of North Korea, the excuse used by North Korea in developing their nuclear weapons was a self-defense act against the threat of military aggression by the United States. The excuse cannot be taken for granted because many things must be defined by international law until North Korea's actions can be regarded as self-defense.

\footnotetext{
$9 \quad$ UNSC Resolution 22762016.

10 Kongdan Oh, "Military Confrontation on the Korean Penisula", Institute for strategic, Political, Security, and Economic Consultancy, 2011, p. 7.

11 Phillip Jessup, A Modern Law of Nation, Bandung: Nuansa, 2012, p. 194
} 


\section{B. THE LEGALITY OF NORTH KOREA'S NUCLEAR WEAPONS DEVELOPMENT BASED ON SELF-DEFENSE PRINCIPLES IN INTERNATIONAL LAW}

Self-defense is basically a right of each country that is acknowledged by international law. As a sovereign entity, a country has the right to take action to protect itself from a threat or attack that could threaten its territory and interests. ${ }^{12}$ Self-defense actions taken by the country is justified even though the action is the use of force. ${ }^{13}$

The use of force is in fact contradicting with the international law principle on Article 2 (4) of the UN Charter, which stated, "All Members shall refrain in their international relations from the threat or use of force against the territorial integrity or political independence of any state, or in any other manner inconsistent with the Purposes of the United Nations."

The principle regulates that every country must refrain themselves to threat or use of force against the territorial integrity and political independence of other countries. Therefore, in order to make self-defense actions of a country not contradict with the non-use of force principle, international law governs selfdefense limitation through Article 51 of the UN Charter and Customary International Law.

Article 51 of the UN Charter governs that a country can do a self-defense action when the country is under a threat of using force or if an armed attack occurs. Based on the article, a threat or use of force is a decisive element whether a country can do a self-defense action or not. The UN Charter textually gives limitation to the threats that can justify a self-defense action to only a threat of using force. It said, "Nothing in the present Charter shall impair the inherent right of individual or collective self-defence if an armed attack occurs against a Member

\footnotetext{
12 Malcom N. Shaw, International Law, Cambridge: University Press, 2008, p. 1141.
}

$13 \quad$ Ibid. of the United Nations, until the Security Council has taken measures necessary to maintain international peace and security. Measures taken by Members in the exercise of this right of self-defence shall be immediately reported to the Security Council and shall not in any way affect the authority and responsibility of the Security Council under the present Charter to take at any time such action as it deems necessary in order to maintain or restore international peace and security". ${ }^{14}$

The definition of a threat of using force is still defined per case because there is no clear definition regarding the threat of using force. Article 51 does not specifically describe the threat of using force criteria so that when the UN deals with a case, the Security Council was given the authority to interpret. Experts agree that the threat of using force is not seen from the type of weapon or the size of the troops, but based on the scale and effect of the armed attack. ${ }^{15}$ threats of using force that fulfill the Article 51 criteria were believed to have a large scale and effect as well as can threaten the territorial integrity of the attacked country. This concept emerged from the Eritrea-Ethiopia Commission in the case of Eritrea v. Ethiopia which said that the attack of small armed forces on the border is not included in the threat of using force referred by the UN Charter even though it causes the loss of life. This is because, according to the Commission, it does not threaten the territorial integrity of a country.

In Nicaragua case, the International Court of Justice assumes that the scope of self defense in customary international law is almost close to definition in Article $51 \mathrm{UN}$ Charter. When UN Charter come into force in 1945, the regulation according to self defence was not only applied when state

\footnotetext{
Article 51 of United Nation Charter.

Para. 237, Nicaragua case (Nicaragua v. United States),
} ICJ Reports, 1998. 
facing armed attack but also within scope of self help. ${ }^{16}$

Armed attack is often known as an act of aggression. The United Nations General Assembly tries to define acts of aggression as in Resolution No. 3314 (1974). Article 8 of Rome Statute limits the act of aggression, "...the use of armed force by a State against the sovereignty, territorial integrity or political independence of another State, or in any other manner inconsistent with the Charter of the United Nations. Any of the following acts, regardless of a declaration of war, shall, in accordance with United Nations General Assembly resolution 3314 (XXIX) of 14 December 1974". ${ }^{17}$

The International Court of Justice uses the aggression definition as in United Nations General Assembly resolution 3314 as a starting point to define armed attack in Nicaragua case, Oil Platform case, and other armed activities. In the resolution, aggression known as the most serious and dangerous form of the illegal use of force. ${ }^{18}$ Some experts argued that use of force has to be distinguished from armed attack, they have to be distinguished by the size of the effect.

Along with the times, the threat of using force definition is increasingly developing. Currently, the weapons used by a country against its enemies are not only weapons used at close range. Now, many countries are starting to develop rocket launchers that can deliver weapons from a long distance.

In addition to rocket launchers, nuclear weapons can also be a threat for countries because of their nature that can destroy quickly and massively so that they can have a mass destruction effect on their objects. Based on its mass destruction nature, the country threatened by nuclear weapons cannot wait until they are attacked to do a

16 Bruno Simma, The Chapter of the United Nations a Commentary, New York: Oxford University Press, 2002, p. 806.

17 Article 8 of Rome Statute.

18 United Nations General Assembly Resolution 3314 (XXIX) of 14 December 1974. self-defense action because the attack will cause massive damage and paralyze all sectors in the country. It becomes one of the reasons for many countries to do preemptive self-defense.

The United States is the first country to declare the preemptive self-defense doctrine as the basis for its attack on Iraq. The United States worried if their country would be attacked by Iraq so that they chose to attack Iraq on 18 March 2003. It was later discovered that Iraq was not proven to have nuclear weapons as alleged by the United States.

A county's right to apply self-defense principles must be followed with caution. A country must be cautious in determining whether the danger it faces actually fulfills the three conditions for doing self-defense implied in customary international law which are necessity, proportionality, and immediacy. ${ }^{19}$

\section{Necessity}

The draft of Article 25 ILC regarding Responsibility of States for Internationally Wrongful Acts stated that necessity is a principle that justifies something usually considered wrong (internationally wrongful act). ${ }^{20}$ In the self-defense application, necessity is a principle in customary international law that determines whether a country is allowed to take self-defense actions or not.

Concerning North Korea's nuclear weapons development program which is claimed as a self-defense action, evidence showing that North Korea has fulfilled the necessity principle is needed. The evidence must show that there is indeed a threat of using force against the country and there are no other alternatives for North Korea to

19 Yoram Dinstein, War, Aggression, and Self Defence: Third Edition, Cambridge: Cambridge University Press, 2003, p. 183.

20 Article 25 of ILC Draft Articles on Responsibility in States for Internationally Wrongful Acts 2001. 
protect itself except by having nuclear weapons. Until now, North Korea does not come under a direct threat of using force from the United States.

The Paris Declaration states, "Every nation is free at all times, and regardless of treaty provisions, to defend its territory from attack or invasion and it alone is competent to decide whether circumstances require recourse to war in self defence. if it has a good cause the world will applaud and not condemn". ${ }^{21}$ Brierly not agree with the statement because that declaration cannot be interpreted literally or not it will be used for political reasons by countries to start war.

\section{Proportionality}

The principle of proportionality requires that actions taken by a country in conducting self-defense must be proportional to the scale and effect of the threat of using force by the opposing country. This principle does not limit the type of weapons that can be used by a country in implementing self-defense. The Adversary Opinion regarding "Legality of the Threat or Use of Nuclear Weapon" explained that the International Court of Justice does not forbid the use of nuclear weapons by a country if the country has the urgency to do self-defense. However, the use of nuclear weapons as a self-defense tool has to consider the applied humanitarian law between countries, including the target of the nuclear weapon. In humanitarian law, there is a distinction between civilian and the military, therefore the weapon should not target civilians. The target has to be calculated when a country is going to use nuclear weapons as a self-defense action because it will cause massive

21 Brierly J.L, The Law of Nations, Oxford: Claredon Press, 1963, p. 407. destruction without differentiating their target.

\section{Immediacy}

Immediacy is on the spot reaction of a country when it faces an armed attack. However, there are disadvantages in the principle of immediacy because the country is a system run by the government and requires bureaucracy in making a decision. Even in a threatening condition, the country needs time to prepare itself to implement selfdefense.

Practically, criteria of immediacy are very difficult to explain. ${ }^{22}$ In 1981, Israel attacked Iraq's nuclear factory. Israel bombed the research center near Baghdad and also destroyed the nuclear reactor with the excuse that Iraq developed nuclear weapons to attack Israel in 1985. In that case, United Nations Security Council decided that the Israeli military action were clearly in violation of the UN Charter and other international laws. The Security Council agreed that Israel was not trying to solve the problem with Iraq peacefully. In addition, Israel also considered failed to prove that the country was under threat of imminent attack by Iraq.

The Chatham House Principles in Principle (d) stated that imminence criteria must be interpreted according to the types of threats. ${ }^{23}$ The principle also stated that the use of force can only be done if the postponement of self-defense can lead to the inability of the attacked country to fight back. In determining the imminence of the attacks, it faces, a country can assess it from the strength of the attack, the ability of the attacker (for example, the attacking country has weapons of mass

22 Michael Wood, "International Law and the Use of Force: What Happens in Practice", Indian Journal of International Law, Vol. 53, p. 358.

$23 \quad$ Ibid. 
destruction), and whether the threat of the attack includes notification or not. ${ }^{24}$

The important thing to implement selfdefense is a good faith from the country to prove that it is under threat of using force. In Article 51 of the UN Charter, the right to do self-defense can only be applied until the Security Council takes over to resolve the problem. The country is required to immediately report to Security Council so that they can take immediate action. ${ }^{25}$

A report made by a country to the Security Council can be an indicator that the country believes its self-defense measures meet the criteria required by international law. This can be seen in the Nicaragua case, the judge stated that if a country does not report the use of force to the Security Council, it will raise doubts whether the selfdefense right is valid or not. ${ }^{26}$

However, the article does not state whether the absence of a report from a country regarding its self-defense action to the Security Council means negating its right to do self-defense. In fact, a country rarely carries out its obligation to report its self-defense actions to the Security Council. However, the good faith of a country to report its self-defense actions is hoped to help the Security Council to evaluate whether the actions are following the applied international law or not.

Self-defense is not an obligation, but an inherent right of every country. It means that international law acknowledges the right of a sovereign country to do selfdefense actions, but it does not mean that self-defense action must be done. A cautious country will definitely think its selfdefense action over because there are no clear restrictions given by international law regarding self-defense actions and also when deciding whether to take self-defense actions or not. The country is given the freedom to judge a condition and its own

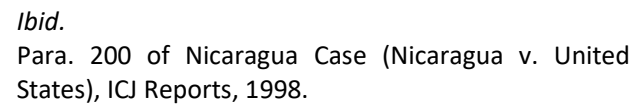

actions whether it is complying with international law or not. The country also has the right to choose the types of weapon used in its self-defense action.

The development of nuclear weapons in North Korea is inseparable from the role of the Soviet Union (currently Russia) which provided science and technology training as a basic knowledge for North Korea in developing nuclear weapons. In 1959, North Korea and the Soviet Union signed a cooperation agreement in nuclear development which is valid for 30 years. During this time, the Soviet Union provided North Korea with training and knowledge on nuclear weapons development. The Soviet Union also helped to study and map the location of uranium sources to be mined in North Korea.

In 1962, the Yongbyon Nuclear Research Center which is the nuclear development center in North Korea was completed and can be used. This research center continuously conducted plutonium enrichment and development until in 1989 their nuclear weapon development program was caught by the United States satellite, thus causing a nuclear crisis between the United States and North Korea.

At the same time, the nuclear weapon proliferation regime had started when the Non-Proliferation Treaty (NPT) was passed in 1970. North Korea also participated in the ratification of NPT in 1985. Therefore, North Korea indirectly agreed that the country will not develop and distribute nuclear weapons and if it has a nuclear development program, then North Korea agreed that the program must be examined by IAEA to make sure that the program was aimed at peaceful purposes.

In 1993, North Korea publicly declared that the country was ready to develop nuclear weapons. In 1950, the relationship between North Korea and the United States 
started to get tensed up. The United States and South Korea conducted joint military exercises a few times. The United States vigilance against North Korea is also carried out by listing North Korea into the axis of evil countries list, which increases the tension between the two countries.

North Korea makes the tension with the United States and its conflict against South Korea as an excuse to develop nuclear weapons. North Korea said that its nuclear program is an act of self-defense towards the United States or South Korea attack. ${ }^{27}$ Even though the tension between the two countries is increasing until now there is no attack committed by the two countries. The United States and North Korea only threatened one another using nuclear weapons if the opponent were believed to attack.

In responding to the United States threat, North Korea cannot predict whether the United States will attack their country with nuclear weapons or not. If indeed the United States will attack using nuclear weapons, North Korea also cannot predict when the weapon is going to be deployed by the United States and its ally. The uncertainty gives North Korea a chance to solve the problem with the United States peacefully. North Korea has time to think of the best method in facing the United States threat which is believed to attack by deploying its nuclear weapon.

In 1994, the United States and North Korea had held a bilateral negotiation to solve the conflict between the two countries due to the nuclear weapon development program of North Korea. The negotiation, which was called the Agreed Framework, stated that North Korea agreed to stop its nuclear weapon development program in exchange for two light-water reactors built by the United States and the supply of heavy oil for North Korea. The negotiation was violated by the United States hence North Korea resumed its nuclear program.
The attempt to resolve the conflict peacefully has proceeded through the Six Talks Party which involved North Korea, South Korea, the United States, China, Russia, and Japan. These negotiations were held from 2003 to 2007 without any significant results because North Korea continued its nuclear program. Based on those facts, it can be seen that North Korea chose to continue its nuclear weapon program and did not want to be involved in peace treaties with the United States and other countries.

In the customary international law, one criterion of self-defense stated by Daniel Webster is "...leaving no choice of means, and no moment for deliberation". The principle governs that the requirement to do self-defense action is fulfilled if a country does not have any other options to save its country in facing threat from other countries and also does not have enough time to decide other measures except selfdefense. There is an element of urgency on the immediacy principle which means that if the country does not immediately take self-defense action, then the country can suffer damage due to attacks by other countries.

In international law, no regulation explicitly forbids a country to use nuclear weapons both in war and in self-defense implementation. Advisory Opinion given by the General Assembly regarding Legality of the Threat or Use of Nuclear Weapons stated that a country might use nuclear weapons as an act of self-defense provided that it must comply with the international law in effect during armed conflict, humanitarian law, and other international law governing nuclear weapons.

In the Rome Statute Article 8B (xx), the use of weapons, bullets, substances, and methods of warfare that might cause excessive injuries and unnecessary suffering are included in war crimes. The Rome Statute does not explicitly state that nuclear weapons are prohibited to use. The Rome

27 Ohn Chang-IL, Op.Cit., p. 37. 
Statute only forbids the use of a weapon, whichever name and type, that might cause the above-mentioned effects.

Humanitarian law also regulates the distinction between combatant (the military) and civilian. In an armed conflict, humanitarian law prohibits military attacks that can injure or kill civilians in the attack.

The nuclear weapon is a weapon of mass destruction with a unique characteristic which is having a large, extensive, and destructive power. The effects caused by nuclear weapons are not only felt by the direct victims of these weapons, but the effects can extend to the next generation. Unlike rifles or knives that can be aimed only at their target, nuclear weapons cannot 'choose' their target. Once deployed, a nuclear weapon is going to hit anyone within its destruction range. Therefore, although there is no international law that explicitly forbid its usage, a threat or the use of a nuclear weapon is against the international law in an armed conflict and is also against the general principles of humanitarian law. ${ }^{28}$

However, the International Court of Justice cannot definitely conclude whether the use of nuclear weapons in an extreme circumstance to do self-defense is allowed or not. The International Court of Justice is still considering the legality of a threat and the use of nuclear weapons when the safety of a country is being threatened even though the use of nuclear weapons, in general, is against the principles of humanitarian law. The International Court of Justice still provides the possibility of using nuclear weapons as an act of selfdefense as long as it meets the criteria on Article 51 of the UN Charter regarding the right of countries to implement selfdefense.

Therefore, North Korea must prove that the country is under a serious threat. As a demonstration of the good faith to do selfdefense in accordance with Article 51 of the
UN Charter, North Korea should immediately report to the United Nations Security Council to help solve the conflict between North Korea and the United States peacefully.

In fact, the relationship between North Korea and the Security Council is not going well. Since 2006, the Security Council had warned North Korea to stop its nuclear program through Resolution 1718. The Security Council believed that the nuclear program is a threat to international peace and security and not in accordance with the NPT spirit.

North Korea feels independent of the NPT. On 10 January 2003, North Korea declared that it retreated from the treaty. Since its withdrawal from the NPT, North Korea is more serious in developing its nuclear program. In 2006, North Korea announced that they had conducted nuclear weapon testing. The action received strong criticism from the Security Council. Comprehensive Nuclear-Test-Ban Treaty (CTBT) explicitly forbids countries to conduct nuclear weapon testing anywhere. North Korea is not a CTBT country, therefore it is not governed by this obligation.

Based on the analysis of self-defense principles on Article 51 of the UN Charter, customary international law, and other regulations that govern the use and possession of nuclear weapons, North Korea's nuclear weapon development program does not fulfill the self-defense criteria required by the international law because the threat faced by North Korea arises due to its nuclear weapon development program and until now there is no use of force done by the United States against North Korea.

The United States and the Security Council have invited North Korea to solve the problem peacefully. Although initially, North Korea was willing to enter the negotiations with the United States as well

28 Advisory Opinion International Court of Justice, Legality of the threat or use of nuclear weapons. 
as the Six Talks Party negotiations, it did not make any progress in resolving the problem. Instead, North Korea continues to develop its nuclear weapon and never reports to the Security Council regarding its self-defense action nor asking for the Security Council consideration for the legality of its nuclear weapon development program if this is the only way to protect itself from other countries' threats. As a member of the United Nations, North Korea is obliged to keep international peace and security. One of the ways to keep international peace and security is by complying with applicable international law and resolving problems in accordance with justified practices under international law. North Korea did not cooperate to solve the problem peacefully and it can make other parties question the integrity and commitment of North Korea on its role to keep the international peace and security.

Those facts showed that the nature of the threat faced by North Korea and the development of nuclear weapons in response to these threats does not fulfill the elements of necessity, proportionality, and immediacy which are required by Article 51 of the UN Charter and customary international law to do a self-defense action.

\section{IMPLEMENTATION OF UNITED NATIONS SECURITY COUNCIL SANCTION ON NORTH KOREA'S NUCLEAR DEVELOPMENT PROGRAM WITH SELF-DEFENSE PRINCIPLES}

1. United Nations Security Council Authority in Imposing Sanctions

Article 24 of the UN Charter authorizes the Security Council to be primarily responsible for maintaining international peace and security. The article stated that the members of the United Nations agree to give the

Article 24 of United Nations Charter 1945.

Huala Adolf, Hukum Penyelesaian Sengketa Internasional, Jakarta: Sinar Grafika, 2006, p. 99. responsibility to maintain international peace and security to the Security Council and agrees that when the Security Council carries out its responsibilities, the Security Council acts on behalf of other members. ${ }^{29}$

This authority is effective in Article 25 of the UN Charter which states that every member of the United Nations agrees to accept and implement the Security Council decisions. Therefore, parties involved are obliged to comply and implement any decisions issued by the Security Council in their function to maintain peace and security and also in the resolution of international disputes. ${ }^{30}$ The conditions on Article 25 of the UN Charter are not only limited to the Security Council actions related to maintaining peace and security based on Chapter VII of the UN Charter but also apply to the Security Council decisions when conducting its primary responsibility in maintaining international peace and security. ${ }^{31}$ Therefore, countries are expected to act in accordance with the declarations made on their behalf.

Security Council members have a big role in determining whether an action taken by members of the UN is a threat to international peace and security. Based on Article 24 (1), it is said that the responsibility to maintain international peace and security is assigned to the Security Council, not only to the permanent members of the Security Council. Practically, the permanent members of the Security Council have a big role in determining a situation and decisions to be made by the Security Council as a whole.

Article 41 of the UN Charter gives the Security Council the authority to impose sanctions and ask other UN members to help the Security Council to 
implement the sanctions. Sanctions imposed by the Security Council might take different forms depending on the purpose of the sanctions. The UN Charter does not explicitly explain the word sanctions in Article 41 but provides a list of actions that might be used by the Security Council to impose sanctions. ${ }^{32}$ Such sanctions might be non-military actions as well as military actions.

Based on Chapter VII of the UN Charter regarding Action with Respect to Threats to the Peace, Breaches of the Peace and Acts of Aggression, the Security Council can impose sanctions on a country if: ${ }^{33}$

a. The country is taking actions that could threaten international peace. Based on Article 34 of the UN Charter, the Security Council might investigate a dispute or a situation leading to international tension or can trigger conflict and determine whether the condition might compromise international peace and security.

b. A country commits a violation of peace when the country fails to follow international regulations such as treaties or the Security Council decisions.

c. Article 39 of the UN Charter authorizes the Security Council to determine a threat to peace, a violation of peace, and an act of aggression. The Security Council is also authorized to give recommendations or choose appropriate actions to restore peace and security.

In the Resolution 1695 of 2006, the Security Council warned North Korea of its ballistic missile launches. The Security Council is concerned that in the future these ballistic missiles can be used to transport nuclear weapons. The concern came with North Korea's nuclear weapon testing in the next 3 months. The Security Council immediately issued warnings and sanctions to North Korea through Resolution 1718 of 2006.

In fact, this is not the first warning issued by the Security Council to a country that carried out nuclear weapon testing. In 1998, the Security Council had given the same warning to India and Pakistan regarding their nuclear weapon testing through 132 Resolution 1172. However, the resolution only contains warnings without any sanction.

In resolution 1718, the Security Council imposed sanctions on North Korea which consisted of an arms embargo, travel ban, asset freeze, financial restriction, and the prohibition on exporting luxury goods. 310 The Security Council also asked North Korea to continue the Six-Party Talks negotiation, to completely stop its nuclear weapon development program, and ask North Korea to cancel its withdrawal from the NPT. The Security Council passed three resolutions that mutually reinforce the previous resolutions. Until now, North Korea is not complying with the Security Council resolutions. It also ignored other countries' pressure that asked it to stop its nuclear program which is believed to threaten the stability of the Korean peninsula and also threaten international peace and security.

In responding to countries' threats of nuclear weapons, the Security Council has a different attitude towards each country. As mentioned above, the Security Council seemed to tolerate and allowed India and Pakistan by indirectly imposing sanctions on the nuclear 
weapon testing of both countries. However, the Security Council directly imposed sanctions on Iran and North Korea.

2. The United Nations Security Council Authorization in Imposing Sanctions Towards North Korea's Nuclear Weapon Development Program as an Act of Self-Defense

The Security Council is a unique international organization because it has the authority to conduct executive, legislative, and judicial functions. Even though it is not an organization that stands above countries, the authority of the Security Council is enormous because they are considered as countries' representatives in conducting their main function to maintain international peace and security. ${ }^{34}$

In conducting its functions, the Security Council is limited by Article 24 (2) stated that "In discharging these duties the Security Council shall act under the Purposes and Principles of the United Nations..."

In the article, it is said that in conducting its function, the Security Council must act in accordance with the purposes and principles of the United Nations. The Security Council must not act in the interests of one or a few countries.

The objectives of the United Nations are explicitly written in Article 1 (1) of the Charter of the United Nations, namely maintaining international peace and security. It said, "To maintain international peace and security, and to that end: to take effective collective measures for the prevention and removal of threats to the peace, and for the suppression of acts of aggression or other breaches of the peace, and to bring about by peaceful means, and in conformity with the principles of justice and international law, adjustment or settlement of international disputes or situations which might lead to a breach of the peace". ${ }^{35}$ However, the Security Council is also obliged to respect the equality of sovereignty and countries' right to defend their political independence. It means that the Security Council cannot impose sanctions or prohibitions on a country that is doing a self-defense action because it is an inherent right of a country and it is acknowledged by international law. At the same time, self-defense actions done by countries should not conflict with the main purpose of the United Nations which is maintaining international peace and security.

North Korea's nuclear weapon development program is a self-defense act against its opponents which are the United States and South Korea. After the Korean War ended with a truce, the United States often conducted a joint military practice with South Korea on the border between North Korea and South Korea. It is natural that North Korea is alarmed and decides to protect itself.

However, as previously discussed, the implementation of self-defense must be following the applicable international law stated in Article 51 of the UN Charter and customary international law. Although the Security Council cannot forbid North Korea to do a self-defense action, it has the authority to control and oversee the self-defense actions taken by North Korea. This is in accordance with Article 51 stated that self-defense actions taken by a country must be reported immediately to the Security Council. North Korea has not only failed to report its self-defense actions but also covers up its nuclear weapons development program. North Korea 
always refuses IAEA inspectors who come there to check and monitor its nuclear program.

In international law, no regulation explicitly forbids a country's ownership of nuclear weapons. Non-Proliferation Treaty (NPT), which is a landmark in international treaties on the prohibition of the distribution of nuclear weapons, does not explicitly forbid countries from developing nuclear weapons. NPT only forbids countries to distribute nuclear weapons and acknowledges its members' right to develop nuclear weapons for peaceful purposes. However, there is a distinctive line between nuclear development for peaceful purposes and nuclear weapon development. Although initially admitted that its nuclear program was aimed to fulfill domestic energy supply, it was proved that the real aim was to produce weapons.

North Korea withdrew from the NPT in 2003. North Korea's independence from the NPT eliminates its obligation to comply with the rules within the agreement. North Korea as a sovereign country is entitled to declare its withdrawal from the NPT. Article 10 of the NPT also respects the rights of its members as a sovereign country and allows its members to withdraw from the NPT if it could compromise the interests of the country.

North Korea's withdrawal from the NPT cannot be prevented because it is a political statement of a sovereign country. However, the Security Council cannot let North Korea abandon its international obligation to maintain peace and security. Through Resolution 1650, the Security Council asks North Korea to continue its obligation on the NPT and IAEA Safeguard, "strongly urge North Korea to return at an early date

36 James D., Legal resolution of Nuclear Non Proliferation Dispute, Cambridge: University Printing House, 2013, p. 152. to the Treaty on Non-Proliferation of Nuclear weapon and International Atomic Energy Agency Safeguards".

Through this resolution, the Security Council seemed to admit that North Korea has withdrawn itself from the NPT. ${ }^{36}$ However, it must be remembered that a country cannot escape from its obligations in Article 25 of the UN Charter. Since becoming a member of the United Nations on 17 September 1991, ${ }^{37}$ North Korea is automatically governed by the UN Charter and is obliged to comply. This includes complying with Article 25 of the UN Charter which contains the willingness of member countries to agree, accept and comply with the decisions of the Security Council under the UN Charter. North Korea withdrawal might be legalized based on Article X of the NPT and Article 56 of the Vienna Convention about Law of Treaty, but there is no international mechanism that enables a country to evade the Security Council resolution. ${ }^{38}$

In Resolution 1718, the Security Council asks North Korea to destroy all its nuclear weapons and stop all of its nuclear programs. The Security Council not only asked North Korea to stop its nuclear program related to nuclear weapon production but also all its nuclear program. This contradicts the NPT itself, which allows countries to have nuclear programs for peaceful purposes. However, Article 103 of the UN Charter said that "In the event of a conflict between the obligations of the Members of the United Nations under the present Charter and their obligations under any other international agreement, their obligations under the present Charter shall prevail".

\footnotetext{
37 United Nations, "Member States", http://www.un.org/en/member-states, accesed on $10^{\text {th }}$ of July 2017.

38 James D., Op.Cit., p. 152.
} 


\section{CONCLUSION}

North Korea's nuclear weapon development program is not fulfilling the requirements in Article 51 of the UN Charter and customary international law regarding self-defense. The threat used as an excuse by North Korea to develop its nuclear weapon does not exist to date and North Korea clearly has a bad intention with its nuclear weapons because it does not want to comply with international procedures to settle the disputes with the United States and South Korea peacefully.

In conducting its obligation to maintain international peace and security, the Security Council has the authorization to take steps that are considered effective to prevent threats to international peace, including determining that a country's nuclear weapons development is considered as a threat to international peace and security. The Security Council is also authorized to impose sanctions on a country that does not comply with its international obligations to maintain international peace and security.

If this authority conflicts with a country's right to do self-defense actions, then the country must prove that its selfdefense actions are following international law. In the case of North Korea's nuclear weapon development, the country does not fulfill the self-defense requirements, therefore the sanctions imposed by the Security Council are not conflicting with the self-defense principles itself.

\section{REFERENCES}

Books

Ambarwati, Hukum Humaniter Internasional Dalam Studi Hubungan Internasional, Raja Grafindo Persada, Jakarta, 2009.

D., James, Legal Resolution of Nuclear NonProliferation Dispute, University Printing House, Cambridge, 2013.
Dinstein, Yoram, War, Aggression, and Self Defence: Third Edition, Cambridge University Press, Cambridge, 2003.

Huala, Adolf, Hukum Penyelesaian Sengketa Internasional, Sinar Grafika, Jakarta, 2014.

J.L, Brierly, The Law of Nations, Claredon Press, Oxford, 1963.

Jessup, Phillip, A Modern Law of Nations, Nuansa, Bandung, 2012.

Simma, Bruno, The Chapter of The United Nations A Commentary, Oxford University Press, New York, 2002.

Wirengjurit, Dian, Kawasan Damai dan Bebas Senjata Nuklir, Penerbit Alumni, Bandung, 2002.

\section{Other Documents}

Chang-II, Ohn, "The Cause of the Korean War, 1950-1953", International Journal of Korean Studies, Vol. 25, No. 2, 2010.

IAEA, "IAEA History", https://www.iaea.org/about/overvie w/history.

ICJ Reports, Nicaragua Case (Nicaragua v. United States), 1998.

ICJ Reports, Oil platform case (Iran v.United States), 2003.

ICJ Reports, Reparation for Injuries Suffered in the Service of the United Nation, 2005.

Oh , Kongdan, "Military Confrontation on the Korean Peninsula", Institute for Strategic, Political, Security, and Economic Consultancy, 2011.

Purwono, Andi and Ahmad Saifuddin, "Peran Nuklir Korea Utara Sebagai Instrumen Diplomasi Politik Internasional", Spektrum : Jurnal IImu Politik Hubungan Internasional, Vol. 7 No. 2, 2010.

United Nations, "Member States", http://www.un.org/en/memberstates/.

Wertz, Daniel, “North Korea's Nuclear Weapons Program", The National Committee on North Korean, 2016.

Wood, Michael, "International Law and the Use of Force: What Happens in 
Practice", Indian Journal of

International Law, Vol. 53, 2013.

Yearbook of the ILC, Vol.II, Part.1, 1980.

\section{Legal Documents}

Advisory Opinion Legality of The Threat or Use of Nuclear Weapons 8 Juli 1996.

Comprehensive Nuclear Test Ban Treaty (CTBT), 1996.

International Atomic Energy Agency Statute, 1956.

Non Proliferation Treaty (NPT), 1968.

Responsibility of States for Internationally Wrongful Acts, 2001.

Rome Statute of International Criminal Court, 1998.

Security Council Resolution No. 2094, 2013. Security Council Resolution No.1441, 2002. Security Council Resolution No.1540, 2004. Security Council Resolution No.1718, 2006. Security Council Resolution No.2267, 2016. Security Council Resolution No.502, 1982. Security Council Resolution No.687, 1991. United Nations Charter, 1945. 